\title{
Rhythms of Images and Sounds in Two Films by Robert Bresson
}

\author{
Luíza Alvim \\ Federal University of Rio de Janeiro (Brazil) \\ E-mail: luizabeatriz@yahoo.com
}

\begin{abstract}
Robert Bresson did not only distribute musical excerpts and sounds in his films, but also often conceived the whole film running in a general rhythm, including the repetition and variation of shots in their contents and length. David Bordwell (1985) considered Bresson's films as examples of the style centred "parametric mode of narration." More than that, after Jean-Louis Provoyeur (2003), we consider that many shots in Bresson's films have a characteristic of "denarrativization," a conception based on musicality, devoid of representational constraints. One example is the tournament sequence in Lancelot of the Lake (Bresson, 1974), in which visual and sound elements are repeated as a "cell" with variations in length, angle of shot and with addition or suppression of elements. The author also analyses some aspects of The Trial of Joan of Arc (1962), in which the rhythmic sensation is created by the procedure of repetitive alternation of image, speech and space. ${ }^{1}$
\end{abstract}

Keywords: Robert Bresson, rhythm in cinema, repetition, denarrativization.

\section{A Rhythmic and Denarrativized Cinema}

The films of French director Robert Bresson employed rhythm as a guiding principle. The director himself stated in his book (written in the form of aphorisms): "Rhythms. The omnipotence of rhythms. Nothing is durable but what is caught up in rhythms" (Bresson 1977, 31). This aspect made many scholars consider them as having a "musical structure," although actual music was utilized with great parsimony.

Rhythm is one of the means by which Michel Chion's (1994 and 2002) concept of transsensoriality materializes in cinema. Chion defines transsensorial

1 An initial version of this paper was presented in the "Visual Culture" Working Group, at the IAMCR conference in Montreal, Canada, July 12-16, 2015. 
perceptions as those which are carried by the channels of more than one sense, just like it happens with rhythm. For Chion, rhythm is not produced by an auditory sensation alone, but by everything that has "sensorial variations:" "rhythm is everywhere; in the past, for example, at night, in the days before the electric lights, it was present in the pulsations of candlelight" (Chion 2002, 57). ${ }^{2}$ In Bresson's films, in addition to the rhythm of sounds and musical excerpts, there is also a rhythm created by elements of repetition and variation in the shots, in their contents or duration. Jean Pelegri stated that, in Bresson's films, it was a matter "of orchestrating the visual rhythms, of composing them in a musical way" (Pelegri 1959, 1). Jean-Louis Provoyeur (2003) considers that Bresson seems to privilege effects of symmetry and repetition: there are often almost identical shots which are constantly repeated along the film or in a sequence which is mostly responsible for the rhythmic sensation in his films. This is also close to what David Bordwell called a "parametric" mode of narration - the other three modes being "classical," "art-cinema" and "historical-materialist narration" (1985). Bordwell suggested the word in reference to the use of the term "parameters" chosen by Noël Burch in his book Theory of Film Practice to describe film techniques like the spatial-temporal manipulation of editing, the possibilities of framing and focus, and so forth. To Bordwell, a parametric narration is a style-centred one, that is, a large-scale structure determined by the stylistic choices of the author and not by the events of the narrative, and in which redundancy is a basic condition. Specifically taking into account Bresson's cinema, extreme repetitiveness is a means to create a parametric narration, as considered by Bordwell.

Moreover, Provoyeur (2003) considers many shots, or images within shots in Bresson's cinema that could be understood as "denarrativized” (dénarrative): they appear devoid of narrative content, as if the narrative and the filmic were separated in them. "The whole aesthetic of Bresson is condensed in the 'denarrativisation,' which makes the image go underneath the filmic narrative, a procedure that he conjugates under multiple forms (deframing, fragmentation, ellipsis, offscreen, tendency to geometry and abstraction etc.), which have the goal to throw outside the image, that representation of the action which makes, since Aristotle, the very material of the narrative.” (Provoyeur 2003, 15, italics in the original.) ${ }^{4}$ Provoyeur

2 Our translation from French. In original: "le rythme est partout; autrefois, par exemple, la nuit, avant la lumière électrique, il se trouvait présent dans la lumière palpitante des chandelles et des bougies."

3 "Il s'agit d'orchestrer des rythmes visuels, de les composer d'une manière musicale."

4 “C'est dans la dénarrativisation, qui fait de l'image en-deça du récit filmique, que se condense toute l'esthétique de Bresson, procédé qu’il décline sous de multiples formes (décadrage, 
does not mean that Bresson's cinema is non-narrative, but, in those moments, the filmic would predominate over the narrative aspect. ${ }^{5}$ Provoyeur then affirms: "the shot in Bresson does not tell, it shows" $(2003,96)$. This may recall the dichotomy evoked by André Gaudreault between "showing” and "telling” in early cinema, in which the very first years were characterized by the aspect of showing, described by Tom Gunning in his concept of "cinema of attractions" (2006). In spite of a supposed victory of the narrative aspect in mainstream cinema, there are many films up to our present days in which the "showing" aspect has predominated. Those denarrative shots in Bresson are such an example.

Although we could argue that in the concept of "denarrativization" there is a kind of return to a supposed purity of cinema advocated by many cinema theoreticians, we consider these so called "denarrative" shots more in the relationships between Bresson's dialogues, lines, and poetry - as stated by Estève (1983) -, eligible to being associated to a sensation of rhythm. This connects Bresson's cinema with the experiences of the avant-gardes in painting and cinema of the 1920s and 1930s, because the denarrative shots grant a major emphasis to formal aspects of the images and sounds, especially repetition and variation, as it happened in the case of the avant-gardes.

Repetition and variation are fundamental in music. At the beginning of the 20th century, the search for a correspondence between image and music was very important in painting, for example, in the work of Francis Picabia, Wassily Kandinsky, Adolf Hölzel, Paul Klee, Robert Delaunay and others. For Karin von Maur (2004), the fascination of those painters for music can be explained by its immateriality and its independence from the injunctions of reproduction of the visible world and that is also why music, an immaterial art, became a model for many abstract paintings.

The temporal dimension led the painter Hans Richter to the cinematograph, in which time is a constitutive aspect. At the beginning of the twenties, Richter made the series Rhythm 21, 22, 23. Trying to define it, he stated: "the articulation of movement, for me, is the Rhythm. And rhythm is the articulated time. And so is in music. But, in film, I articulate time visually, while in music I articulate it

fragmentation, ellipse, hors-champ, tendance à la géométrie et à l’abstraction etc.) qui, toutes, visent à rejeter hors de l'image cette représentation de l'action fait, depuis Aristote, la matière même du récit."

5 Bordwell also considers that the dominance of style is not in abstract or nonnarrative films, and his "parametric mode of narration" is applied to films in which there is still a syuzhet (the selection and organization of story events) (1985). Bresson's films are actually examples eluded by Bordwell. 
by ear" (Richter in Maur 2004, 161). It is a statement close to some of Bresson's, as the French director considered - above all in his film-making - the rhythm generated by the repetition of images and sounds, much more than the injunctions of the narrative: "all those effects you can get from the repetition (of an image, of a sound)" (Bresson 1977, 26). Bresson also considered the correspondence of images with music. "Images. Like the modulations in music." (Bresson 1977, 26.) For Jean Mitry, the experiences of the avant-garde cinema of the 1920s aimed to construct a "visual music [...] by means of a significant rhythm in itself" (Mitry 2001, 174). ${ }^{6}$ Château (1992) remarks that those films were silent, that is, even if they had musical accompaniment in their exhibition, the musicality should be, as observed by Mitry, something intrinsic to the images in movement. The common aspect between painting or silent cinema and music would reside in rhythm.

Nevertheless, sounds were very important in Bresson's cinema and they construct, together with the images, the whole rhythmical sensation transmitted by it. At the beginnings of sound cinema, the search for a correspondence between cinema and music appears very clearly in the writings from the thirties and the forties of director Sergei Eisenstein (2002), who takes into account the sound of music as well. Considering movement as a common trait between cinematic images and music, Eisenstein tried to elaborate a model of correspondence between them. The rhythm was a fundamental aspect for Eisenstein, that is, the "key to the measured matching of a strip of music and a strip of picture" (Eisenstein 2002, 105, italics in the original). It is the case of the conception of the "Ice Battle" sequence of Alexandre Nevsky (Eisenstein, 1938), which was analysed in details by the director himself (Eisenstein 2002). At the beginning of the sequence, two musical phrases by Sergei Prokofiev (the composer of the film music) are alternated, not always coinciding with the change of shots. Eisenstein explained that the "gestures" could be interpreted as musical (for example, the first chord in each musical phrase functions as a "starting platform") as much as the movements of the eye along the frame (in shot 8 of the sequence, for example, it passes from the character in the foreground to the line of soldiers in the distance and to the right).

"Bend context to form and sense to rhythms," stated Bresson $(1977,31)$, who also expressed an expectancy of a kind of correspondence between images and sounds when creating a film. "Dig into your sensation. Look at what there is within. Don’t analyze it with words. Translate it into sister images, into equivalent

6 "Faire du cinéma une musique visuelle, s'exprimer au moyen d'un rythme signifiant par luimême." 
sounds. The clearer it is, the more your style affirms itself." (Bresson 1977, 27.) Film-making for Bresson was the materialization of complex sensations into images and sounds. It was the affirmation of a style, as in the definition of Bordwell's "parametric mode of narration."

Provoyeur (2003) also considers an approximation between Bresson and the soviet avant-garde ${ }^{7}$ as both have editing as a very important principle. "Cutting. Passage of dead images to living images. Everything blossoms afresh" - wrote Bresson $(1977,43)$. He considered that separate pieces (images, sounds, elements of a shot) would gain a new dependence when put together and that would be the very step in the creation of film as an artwork (Bresson 1977). Moreover, the great fragmentation characteristic of Bresson's editing emphasizes the sensation of repetition and variation that will generate a sensation of rhythm in his films.

\section{Bresson: Repetitions and Variations - the Omnipotence of Rhythms}

In Bresson's films, shots of doors, stairs, elevators, and so on are particularly frequent and the sound associated with them is also essential. Precisely those shots led many critics to describe his films as tedious and repetitive, in a pejorative sense. For example, already in 1945 (in relation to a film that is usually considered as pre-bressonian, that is, before the consolidation of Bresson's style), Luc Estang (1945) wrote an ironic criticism about the shots of characters climbing up and down the stairs and elevators in The Dames of Bois de Boulogne (Les dames du Bois de Boulogne), in a quite exhaustive list, which, under a different perspective, constitutes for us an extensive panorama of the film's vertical rhythms. According to the critic's description: the character Hélène, coming home from the theatre, takes the elevator; her lover Jean gets into it to go down after the conversation with her; she climbs the stairs to meet Agnès and her mother (the "dames" of Bois de Boulogne) in their apartment; the two of them also get to their new home climbing up the stairs; they climb down to talk on the telephone in the building's hall and up again, as each conversation finishes; after the first sequence in the Bois de Boulogne, Jean and Hélène go up and down with the elevator; Jean climbs up the stairs of Agnès's apartment to visit her; there is also a movement of double descent - elevator and stairs - as Jean leaves suddenly Hélène's home taking the elevator and she reaches him getting down the stairs; and so forth.

$7 \quad$ To Bordwell (1985), the soviet avant-garde would employ another mode of narration, which would have its fundamental principle in the rhetoric. 
A similar list, more or less extensive, could be made based on Bresson's other films. His preference for shots of doors, stairs and elevators is one of the aspects considered by Provoyeur (2003) as denarrative in Bresson's cinema. They usually begin as empty spaces, which a character enters and then leaves it again empty to go back to the offscreen space (a space that has an essential role in Bresson's films and where many actions, the narrative itself, take place). They can also be fragmented, containing only part of a character's body or of an object, like the ones we see in the tournament's sequence in Lancelot of the Lake (Lancelot du lac, 1974).

Moreover, in many films by Bresson, we can consider that there are what we will designate here as "cells of image and sound:" a series of shots which is repeated, mostly with variations, all over the film or in a single sequence, like the tournament sequence of Lancelot of the Lake that we are going to analyse later. In A Gentle Woman (Une femme douce, Robert Bresson, 1969), the shots of the maid opening the curtains in the morning function as such a cell. The film, a Dostoyevsky adaptation of the novel with the same title, handles about the suicide of a young woman, after being continuously humiliated by her husband, the owner of a pawnshop, in which she was a former client. The shots of the maid shows a routine, although we shall say, in the sense pointed out by Deleuze, that repetition never belongs to the order of the Same and contains in itself the difference (Deleuze 1968). For example, after the protagonist couple's big crisis - the one in which the wife puts a gun to the husband's head in the middle of the night - the opening of the curtains in the next morning brings a feeling of suspense: would the husband be hurt? (Dead he cannot be, as he is the one who tells us the story and appears in the present.) In a later sequence, after the wife's night of feverish delirium, the opening of curtains could point to a feeling of relief, as a new day begins, or to the inexorable march to her suicide. Then, the same action of opening the curtains gets in each of those sequences a different feeling and signification.

In this film, another fundamental repeated cell, the one of the suicide of the main female character, forms an enveloping frame, as it can be found at the beginning and at the end of the film. Confirming the rhythmic function of such an enveloping frame, we observe that, in many of his films, Bresson employed excerpts of the same musical piece at the beginning and at the end. It is the case of the roll of drums in The Trial of Joan of Arc (Le process de Jeanne d'Arc, 1962) and of the excerpts from Monteverdi's Magnificat in Mouchette (Bresson, 1967). Because of the presence of rhythmic cells with greater evidence in them, we will now focus on The Trial of Joan of ArC and Lancelot of the Lake. 


\section{The Rhythm of Alternations of Spaces and Speeches in The Trial of Joan of Arc}

The Trial of Joan of Arc is composed by a series of interrogatories, which Bresson took from the authentic texts of Joan of Arc's trial in Rouen in the 15th century. The rhythm of the film is a result from the recurrence of sounds of doors, footsteps climbing up and down the stairs, as well from the alternation of many elements: the inquisitors' questions and Joan's answers; the spaces of the courtroom and of Joan's cell (at the beginning of the film [Figs. 1a and 1b]) or the alternation between the cell and the corridor (when the interrogatories move to the very cell of the prisoner); finally, there is also the ping-pong of shot and reverse-shot technique, which constitutes the basis of almost the entire film.

As for that last element, each one of the shots of shot and reverse shot has a different duration: the camera sometimes focuses only Joan's face and we hear the off-screen inquisitor's voice, and vice versa; there are also sequences in which the person who speaks is always on-screen. Those different combinations of what is on- or off-screen help to create the film's general rhythm.

Pichonnier (Fiches filmographique, no. 184) considers the general rhythm in The Trial of Joan of Arc as a result of many elements: the succession of spaces; the dialogue's pattern, which is based on the alternation of questions and answers; shot and reverse-shot technique; the repetition of terms inside a speech or in different speeches; the periodic retaking of the main themes of accusation; the regular use of speech lines in English (the cries of the public: "Burn the witch!").

Regarding the spaces, we have, from the first interrogatory until the first admonition of bishop Cauchon, a pattern in which the space of the courtroom (which is the initial place of the interrogatories) alternates with the space of Joan's cell. This pattern is partially interrupted (we shall recall that such ruptures of rhythms and atmospheres are also utilized, in an expressive way, in musical pieces in general) when the interrogatories are moved from the courtroom, where we have a sound design containing the public's bustle, with the punctuation of speech lines in English, to Joan's own cell. In this space, we lose the composition of all those sound elements, while, in compensation, the characteristic of alternation gets even stronger between Joan in her cell and the Englishman Warwick, her enemy, in the corridor (there are even some moments, when the image of the interrogatory is shown from Warwick's point of view, through the keyhole, as well as from his point of listening, with a reduction of the sound volume). 
The pattern of alternation of spaces continues almost unchanged in the film until a very important rupture of rhythm happens at the end, when Joan is brought to her execution. Jean De Bongnie (1967) considers that at that moment the film loses the staccato of the alternations in a speedy pace, which had dominated until then, - the rhythm of the "intrepid confrontation" -, to become a sustained "organ note" at the image of the vanishing smoke over the stake where Joan was burned.

\section{Difference and Repetition in Lancelot of the Lake}

Lancelot of the Lake is based on the legendary stories about Arthurian Round Table and the love between Lancelot and Guinevere. In the film, the knights are back at Arthur's castle after the frustrated search for the Holy Grail. It is a moment of crisis and an invitation to a tournament is accepted with joy, while the knight Mordred tries to unveil the forbidden love of Guinevere and Lancelot and plots against Arthur.

Rhythmic patterns of sounds and images are very important all along the film, especially in the tournament's sequence. Altogether in it, we hear the bagpipe nine times, with the same melody that announces the beginning of what we are calling rhythmic-melodic-audio-visual ${ }^{8}$ cell: bagpipe (image and /or sound) - flag - horse's legs - Gawain's face - image and /or sound of the spear [Figs. 2a-2d].

This cell is repeated and varied all over the sequence, as stated by Baroncelli (1974), Martin (1974) and Cugier (1985). "The repetition of the same action, in which, each time, one of the elements is modified from a basic structure [...]: bagpipe - flag - horse. Then, the elements vary and tighten themselves, the themes are articulated (the stands, the spear, the falls, the crowd's bustle, the 'Lancelot' pronounced by Gawain) till the departure of the knight in the white shield [...]. Each element refers to the whole and everything is a matter of rhythms." (Martin 1974, 100.) "The tournament episode, where everything is suggested by the serial combination of some rigorously selected visual and sound elements: bagpipes' music, ascent of flags, backs of horses launched to gallop, noises of disjointed armors." (Baroncelli 1964, 15.) "That universe of details, of burst elements, is propelled forward by the repetition-transformation of elementary cells (for example: bagpipe, flag, horse, fall), serial combinations which include light modifications, alterations, variations of shot angles." (Cugier

8 It is rhythmic because of the way of the succession of shots, melodic due to the bagpipe, and audio-visual, as there are, like in Chion's (1994) concept, sounds and images creating a meaning together. 
$1985,123.)^{9}$ Although two of the above quotes refer to "serial combinations," the way in which the sequence is edited resembles much closer the minimal music ${ }^{10}$ of Phillip Glass and Steve Reich than the Serialism of Schoenberg. Therefore, similarly to what happens in the minimal music and as Martin (1974) considered, we observe that the basic cell is gradually varied and receives new elements, like the images of the fallen knights (knocked down by Lancelot), and Gawain's speech ("Lancelot!"). Bordwell (1985) also considered that parametric narration, to which Bresson's cinema is an example, has characteristically an additive pattern, not a serial one. ${ }^{11}$

On the other hand, the somewhat stereotyped aspect of the tournament sequence is also an evocation of the film's medieval sources, in which the repetition of a sequence of actions with additive elements also occurs. In his notes to Lancelot ou le chevalier à la charrette, Jean-Claude Aubauilly describes: "same notations, same progression, same ending. Horse battle with spear, then with sword if none of the two knights fell down from the horse at the moment of the first confrontation; then, battle on foot, with sword; battle for a long time indecisive with serious wounds to both parts and, finally, the victory of the hero, who forces the opponent to ask for mercy, as he cuts the straps of his protecting helmet" (Note to Chrétien de Troyes 1991, 439).

A similar succession of the battle phases occurs in the tournament of prose narrative The Death of King Arthur. "So Lancelot stand in the stirrups, got into the middle of the rows and hurt the knight that he first met in his direction so heavily,

9 "La répétition d'une même action, mais en modifiant chaque fois un élément, à partir d'une structure de base $[\ldots]$ : cornemuse-oriflamme-cheval. Ensuite les éléments varient et se resserrent, des thèmes s'articulent (la tribune, la lance, les chutes, la rumeur de la foule, le 'Lancelot' prononcé par Gauvain) jusqu'au départ du chevalier au bouclier blanc. [...] Chaque élément renvoie à l'ensemble, et tout est affaire de rythmes." (Martin, 1974.) "L'épisode du tournoi, où tout est suggéré par la combinaison sérielle de quelques éléments visuelles et sonores rigoureusement sélectionnés: musique des cornemuses, montée des oriflammes, croupes des chevaux lancés au galop, fracas des armures disjointes." (Baroncelli, 1974.) "Cet univers de détails, d'éléments éclatés est propulsé vers l'avant par la répétition-transformation de cellules élémentaires (exemple: cornemuse, oriflamme, cheval, chute), combinaisons serielles qui comportent de légères modifications, altérations, variations d'angles de prises de vue.” (Cugier, 1985.)

10 The Minimal music has characteristics like: the reiteration of elements, a steady pulse, a gradual transformation and, often, additive process and phase shift. In his analysis of that sequence, André Targe (1989) also mentions the music of Phillip Glass, but the author restrains these comparison only to part of the sequence (between Gawain's recognition of Lancelot and the close-up of the spear) due to its greater repetitive and symmetric character.

11 Bordwell (1985) also evokes a possible influence of integral Serialism in the rise of parametric narration in Modern Cinema, but he gets to the conclusion that this narration mode functions more in the additive manner of the musical forms of "theme and variations" or "rondo" than in the complex way of Serialism. 
that he knocked him and his horse down to the earth; he spurred again the horse to gallop, because his spear was not broken yet, struck another knight and hurt him in such a way that neither shield nor harness prevented a grim and deep wound in the left side, but he was not deadly wounded. He struck him violently, so that he fell down from the horse so heavily, that he got dazed with the fall and his spear broke into pieces [...]. And Lancelot, as soon he had his spear broken, took his sword and began to give great blows to the right and to the left and to strike knights and to kill horses and to take shields off from the necks and helmets from the heads." (A morte do rei Arthur 1999, 35-37, our translation from Portuguese.)

According to André Targe (1989), there are, in the whole sequence of the film, three points of change of the initial cell and their beginnings coincide with the shot of Gawain's gaze (one of these is the already mentioned moment, when we hear, for the first time, the only word spoken in the whole sequence, "Lancelot"): Lancelot's arrival; his recognition by Gawain and the shots from Lancelot's point of view of his opponents; the close-up of the spear, that, in its turn, cancels the images of the flag's raising and of the bagpipe.

For example, by Lancelot's arrival, the cell is even prematurely aborted: we only hear the sound of the bagpipe over its image and the raising of the flag: all that comes after that can be considered the beginning of another cell, as the new-comer prepares himself for the tournament under Gawain's curious gaze. From that moment on, the element of the opponents' fall from the horse is included in the cell.

The last cell has something like an extension in the end, as we see a sequence of similar and small shots of a series of knights being knocked down by Lancelot. The accelerated editing that occurs then confirms Lancelot's invincibility and reminds us of the repeated short shots of the trees being cut down in Bresson's next film, The Devil Probably (Le diable probablement, 1977).

It is also important to consider the role of sound, which is employed many times, as usual in other films by Bresson, in anticipation to the image or offscreen. Bresson stated that the tournament's sequence "was edited by ear" (and the director continues the phrase: "as, indeed, all the others in the end" - Arbois 1974). ${ }^{12}$ As a matter of fact, the use of sound is an element of the variations of the cell. Sometimes, the sound of the bagpipe comes before its image, or we do not even see it. In the majority of times, the sound of the spear's shock against the opponent's shield is heard over the shot of Gawain and Arthur in the stands. It is

12 "La séquence du tournoi a été montée par l'oreille [...] comme d'ailleurs finalement toutes les autres." 
precisely because of those discrepancies between image and sound that the first point of synchronization ${ }^{13}$ of the sound of the spear with its image - identified by Targe (1989) as the shot 53 of the sequence - gets emphasized. As Targe (1989) observes, this very point marks also the semantic relationship between the name Lancelot and his weapon, the lance.

The tournament's sequence is an example, in Bresson's works, of a repetition that is not simply the return of the Same, but that contains the difference (Deleuze, 1968), as Targe considers: "the apparent repetition is never sterile, redistribution of the same. It is the sign of permanent mutation, an invitation to break the canons of cinematographic representation. Mobilized in all the extension of its technical codes, the material brings into play its own history, tells us of rhythm, symmetry, explosions. Reaching the moment of equilibrium, it scuttles its organizing principles to invent others, continuously" $(1989,97) .{ }^{14}$

There are other repetitive series showing the same action in Lancelot of the Lake. For example, when the knights depart to the war against Mordred, there is a quite accelerated editing, with many successive shots of horses being saddled - swords being put in their cases - knights mounting their horses - helmets' visors being moved down - spears being given to the knights. The helmet is an important element in the punctuation of the sequence just before the tournament, when, on their way and riding their horses, Arthur, Gawain, Mordred and other knights wonder about Lancelot's whereabouts. Each character that gets into the conversation has his first speech preceded by the lifting of his helmet's visor, the sound of which coincides sometimes with a horse's neigh. The end of the conversation is precisely marked by the lowering of Gawain's visor.

\section{Conclusion}

Rhythm is more than a sole musical concept. It is constituted by different senses, a transsensorial (Chion1994 and 2002) perception. On the other hand, not only sounds but also images can be understood as having rhythm. Paintings and silent abstract films of the 1920s are an example of that.

13 The point of synchronization is actually a concept by Michel Chion (1994): it is a salient moment of synchronous encounter between concomitant audio and visual elements.

14 "l”apparente répétitions n'est jamais stérile, redistribution du même. Elle est l'indice d'une mutation permanente, invitation à briser les canons de la représentation cinématographique. Mobilisée sur toute l'étendue de ses codes techniques, la matière met en scène sa propre histoire, nous parle de rythme, de symétrie, de rayonnement. Parvenue à l'instant d'équilibre, elle saborde ses principes organisateurs pour en inventer d'autres, continuellement." 
In the films of Robert Bresson, we observe a great concern with the rhythm of images and sounds acting together. It occurs, for example, as a consequence of the repetition and variation of what we have called "cells," a set of shots or images and sounds which recur in a single sequence or across the film. Many of them, such as the frequent shots of doors being opened and closed, would be dispensable in the editing in a traditional cinematography and have a "denarrative effect." As those shots are more linked to film form than to the narrative (like in Bordwell's "parametric mode of narration"), they can be used for the sake of creating rhythm, by means of repetition and variation, getting more approached to a musical conception and less dependent on representational constraints. In the tournament sequence in Lancelot of the Lake a cell constituted by the image/ sound of a bagpipe, the raising of a flag, horses' legs, Gawain's face and a spear is repeated and varied in an additive (with additional shots, for instance, the close-up of the spear) or subtractive manner (having some of the shots, like the image of the bagpipe or of the flag eliminated). The extreme repetitiveness of the sequence and the additive procedure also refer to the medieval sources on which the film is based. As for The Trial of Joan of Arc, the rhythmic sensation is created by a procedure of repetitive alternation: of images (intense use of shot and reverse shot), of speeches (the questions and answers of the trial) and spaces (the alternation between the court and Joan's cell in the first half of the film and, then, between Joan's cell and the corridor of the prison).

\section{References}

Anônimo. 1999. A morte do rei Arthur [The Death of King Arthur]. São Paulo: Martins Fontes.

Arbois, Janick. 1974. Le rêve de Bresson - Lancelot du Lac [Bresson's Dream Lancelot of the Lake]. Télérama, September 14.

Baroncelli, Jean de. 1974. Lancelot du lac de Robert Bresson [Lancelot of the Lake by Robert Bresson]. Le Monde, September 26: 15.

Bongnie, Jean de. 1967. Le procès de Jeanne d'Arc [The Trial of Joan of Arc]. Les Amis du Film et de la Télévision no.170 (March): 54-55.

Bordwell, David. 1985. Narration in the Fiction Film. Madison, WI: University of Wisconsin Press.

Bresson, Robert. 1977. Notes on Cinematography. New York: Urizen Books.

Château, Dominique. 1992. Le rôle de la musique dans la définition du cinéma comme art: à propos de l'avant-garde des années 20 [The Role of Music in the 
Definition of Cinema as Art: about the Avant-Garde of the 1920s]. Cinémas: revue d'études cinématographiques vol. 3, no. 1: 78-94.

Chion, Michel. 1994. Audio-Vision: Sound on Screen. New York: Columbia University Press.

Chion, Michel. 2002. Le Son [Sound]. Paris: Nathan.

Chrétien de Troyes. 1991. Lancelot, ou le chevalier de la charrette [Lancelot, the Knight of the Cart]. Paris: Flammarion.

Cugier, Alphonse. 1985. Lancelot du Lac de Robert Bresson - Le Moyen Âge revisité ou la dimension tragique du XXe siècle [Robert Bresson's Lancelot of the Lake - the Middle Ages Revisited or the Tragic Dimension of the 20th Century]. Les Cahiers de la Cinémathèque no. 42-43:119-124.

Deleuze, Gilles. 1968. Différence et répétition [Difference and Repetition]. Paris: Presses Universitaires de France.

Duplaix, Sophie and Marcella Lista, eds. 2004. Sons $\&$ Lumières: une histoire du son dans l'art du XX $X^{e}$ siècle [Sounds and Lights: A History of Sound in 20thcentury Art]. Paris: Éditions du Centre Pompidou.

Eisenstein, Sergei. 1957. The Film Sense. New York: Meridian Books.

Eisenstein, Sergei. 2002. O sentido do filme [The Film Sense]. Rio de Janeiro: Zahar.

Estang, Luc. 1945. Les dames du Bois de Boulogne [The Ladies of the Bois de Boulogne]. Les Étoiles, October 2.

Estève, Michel. 1983. Robert Bresson, la passion du cinématographe [Robert Bresson, the Passion of the Cinematographer]. Paris: Albatros.

Gunning, Tom. 2006. The Cinema of Attraction[s]: Early Film, its Spectator and the Avant-Garde. In The Cinema of Attractions Reloaded, ed. Wanda Strauven, 381-388. Amsterdam: Amsterdam University Press.

Martin, Paul-Louis. 1974. Lancelot. Image et Son [Lancelot: Image and Sound]. La Revue du Cinéma, no. 291 (December): 98-101.

Maur, Karin von. 2004. Bach et l'art de la fugue: Modèle structurel musical pour la création d'un langage pictural abstrait [Bach and the Art of Fugue: A Musical Structural Model for the Creation of an Abstract Pictorial Language]. In Sons \& Lumières: une histoire du son dans l'art du XX $X^{e}$ siècle, eds. Sophie Duplaix and Marcella Lista, 17-27. Paris: Éditions du Centre Pompidou.

Mitry, Jean. 2001. Esthétique et psychologie du cinéma [The Aesthetics and Psychology of the Cinemal. Paris: Cerf.

Pelegri, Jean. 1959. Robert Bresson ou la fascination [Robert Bresson or Fascination]. Les Lettres Françaises, December 31: 1. 
Pichonnier, Catherine. n.d. Le procès de Jeanne d'Arc. Fiche filmographique IDHEC, no. 184.

Provoyeur, Jean-Louis. 2003. Le cinema de Robert Bresson: de l'effet de réel à l'effet du sublime [The Cinema of Robert Bresson: from the Effect of Reality to the Effect of the Sublime]. Paris: L'Harmattan.

Targe, André. 1989. Ici l'espace naît du temps... (Etude detaillée du segment central de 'Lancelot du Lac') [Here Space is Born of Time... A Detailed Etude about a Central Segment in 'Lancelot du Lac']. Camera/Stylo, January 5: 87-99.

\section{List of Figures}

Figure 1a: First interrogatory of The Trial of Joan of Arc: the courtroom. Figure 1b: After the first interrogatory of The Trial of Joan of Arc: Joan in her cell.
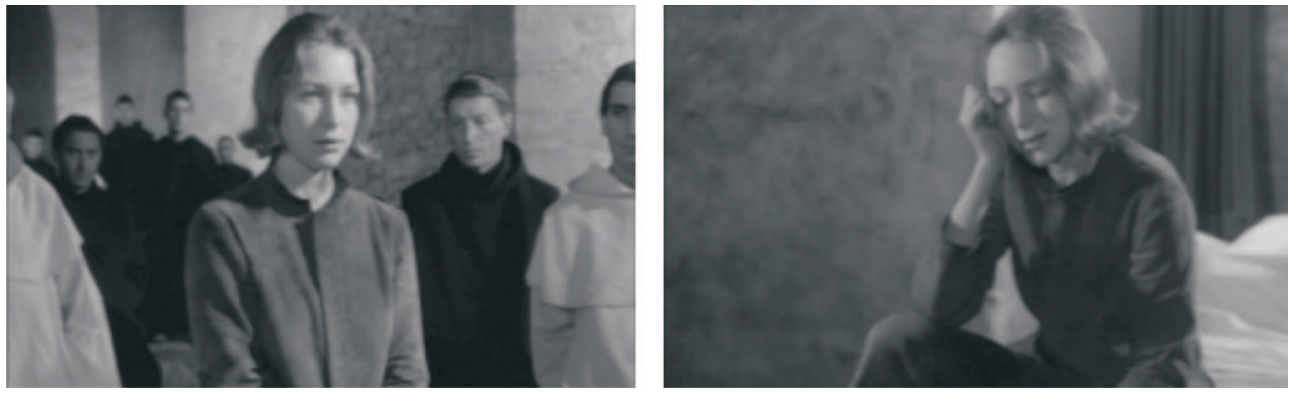

Figure 2a. Beginning of the first cell of the tournament sequence in Lancelot of the Lake: image of the flag to the sound of the bagpipe. Figure $\mathbf{2 b}$. Continuation of the first cell of the tournament sequence in Lancelot of the Lake: image and sound of the bagpipe.
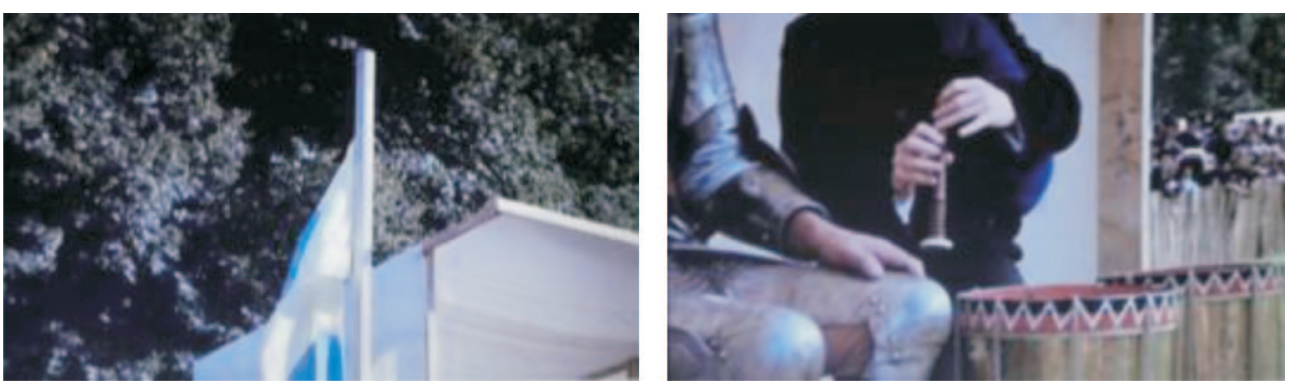
Figure 2c. Continuation of the first cell of the tournament sequence in Lancelot of the Lake: horse's legs. Figure 2d. Continuation of the first cell of the tournament sequence in Lancelot of the Lake: Gawain's face.
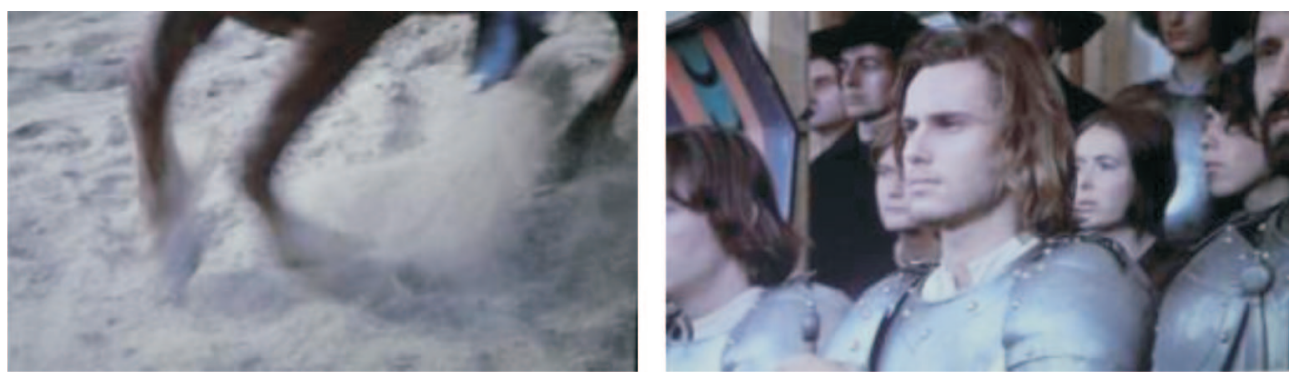